\title{
Archibaldovo znamení
}

\section{MUDr. Jan Papež', prof. MUDr. Zdeněk Doležel, CSc. ${ }^{1}$, MUDr. Jiří Štarha, Ph.D. ', MUDr. Petr Jabandžiev' ${ }^{1}$ MUDr. Jana Šulákováa ${ }^{2}$ MUDr. Jan Šenkyřík ${ }^{3}$}

'Pediatrická klinika LF MU a FN Brno

${ }^{2}$ Oddělení lékařské genetiky FN Brno

${ }^{3}$ Klinika dětské radiologie LF MU a FN Brno

Klíčová slova: Archibaldovo znamení, pseudohypoparatyreóza, hypokalcémie.

Key words: Archibald's sign, pseudohypoparathyroidism, hypocalcemia.

Obr. 1. Vyhlazení nad 4. metakarpofalangeálními klouby obou rukou na podladě zkrácení 4. metakarpü

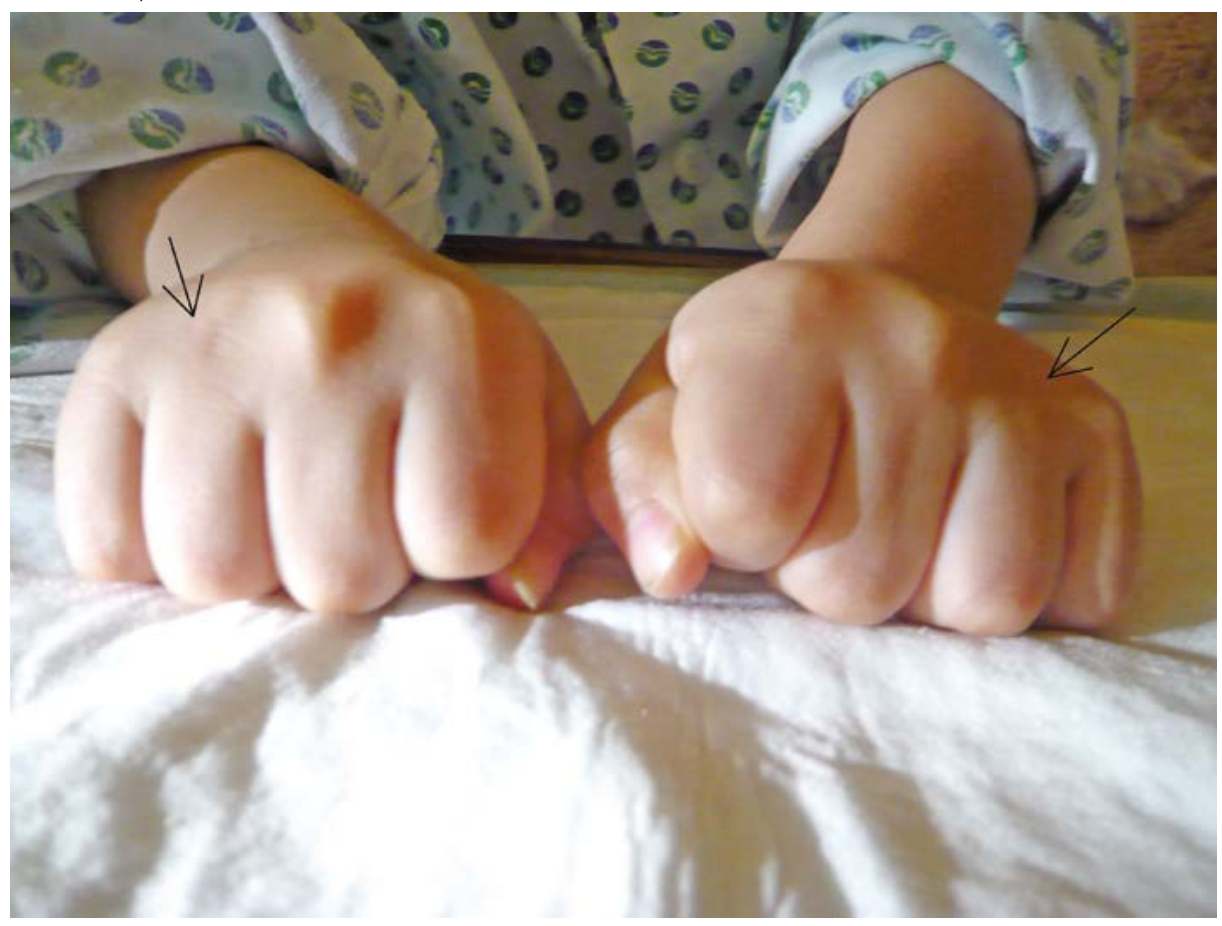

Čtyřletý chlapec sledovaný v endokrinologické ambulanci pro deficit růstového hormonu, small for gestational age (SGA) a primární hypotyreózu, $v$ alergologické ambulanci pro astma bronchiale a v neurologické ambulanci pro opoždění vývoje řeči byl prijiat k hospitalizaci pro hypokalcémii nově zjištěnou při poslední kontrole na endokrinologii. Chlapec měl trvalou farmakoterapii Omitrope, Euthyrox, Flixotide, Singulair, Vigantol. Při vstupním vyšetření nebyly přítomny žádné klinické známky hypokalcémie, nález na EKG byl normální. Ve vstupní laboratoři byla př́tomna výrazná hypokalcémie 1,37 mmol/l ( $\mathrm{Ca}^{++}$0,72 $\left.\mathrm{mmol} / \mathrm{l}\right)$ a hyperfosfatémie 2,47 mmol/l; sérové koncentrace ostatních elektrolytů, alkalické fosfatázy,
Obr. 2. Rtg levé ruky, Archibaldovo znamení (vysvětlenív textu)

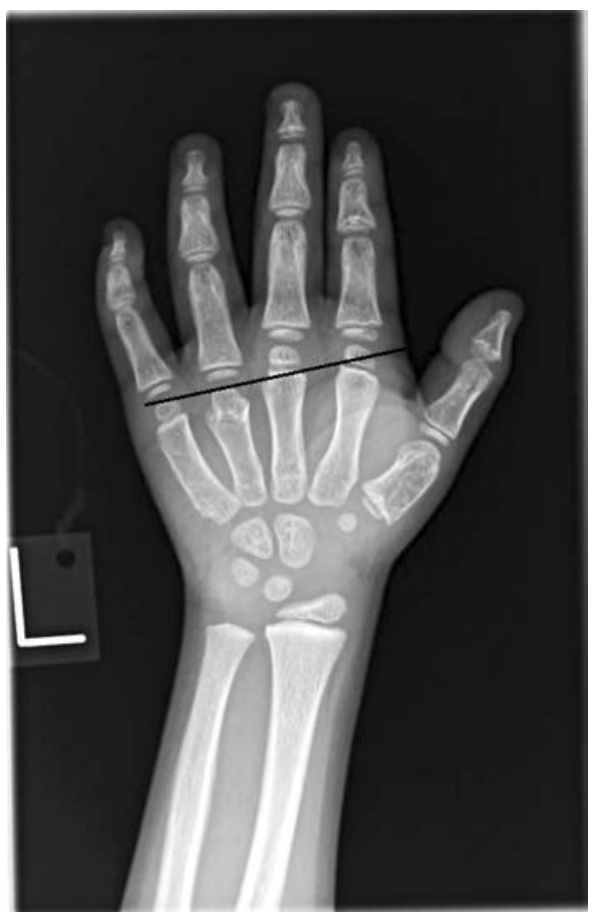

albuminu a $250 H$ vitaminu D byly v normálním rozmezí, bez odchylek byly také hodnoty acidobazické rovnováhy. Hladina parathormonu (PTH) ze dvou různých měření byla výrazně zvýšená (22,4 resp. 27,0; [normální hodnota 1,6-6 pmol//]).

Z výsledků provedených vyšetření bylo vysloveno podež̌ení na pseudohypoparaty- 
reózu (PHP) a léčba byla zahájena podáváním vápníku a kalcitriolu. Při této medikaci došlo k poklesu hladiny PTH a postupné normalizaci kalcémie a fosfatémie. $\mathrm{K}$ definitivnímu stanovení diagnózy bylo provedeno vyšetření genu GNAS1, který kóduje stimulační alfa-podjednotku G proteinu (Gs alfa) asociovaného s hormonálními receptory. $U$ probanda byla nalezena intronová mutace c.312+5G>A; jde o inaktivační mutaci, která již dříve byla literárně uvedena.

PHP je heterogenní skupina poruch, pro které je společná rezistence cílových orgánů na PTH a současně doprovodný biochemický nález hypoparatyreózy (normo/hypo-kalcémie a hyperfosfatémie). Prevalence PHP se udává 0,79 na 100 tisíc obyvatel. Dle rozdílné patogeneze a fenotypu se PHP rozděluje do 4 klinických jednotek - PHP la, Ib, Ic a II.
Náš pacient měl PHP typ la. Pro tyto jedince je typický fenotyp nazývaný Albrightova hereditární osteodystrofie (AHO): různý stupeň mentální retardace, malá postava s krátkým krkem, centrální obezita, kulatý obličej a podkožní osifikace. Nejčastějším klinickým nálezem u PHP la je tzv. Archibaldovo znamení (AZ), což je popisný název pro zkrácení čtvrtého a prípadně také pátého prstu, které se klinicky projeví vyhlazením nad metakarpofalangeálními klouby príslušných prstů na ruce zavřené $\checkmark$ pěst (obr. 1). Literárně bývá AZ promiskue označováno také jako Archibaldovo metakarpální znamení/pozitivní metakaprální znamení/ metakarpální znamení.

Metakarpální znamení poprvé popsali Archibald, Finby a De Vito v roce 1959. Závisí na relativní délce laterálních tři metakarpálních kostí. Tečna spojující hlavičku pátého a čtvrtého metakarpu prochází za normálních okolností distálně od hlavičky třetího metakarpu (negativní metakarpální znamení). U některých jedinců se tato tečna dotýká rovněž hlavičky třetího metakarpu (hraniční metakarpální znamení). Pokud tato myšlená čára protíná třetí metakarpus, jedná se o pozitivní metakarpální znamení (obr. 2). Jedinci s tímto nálezem mají obvykle opožděný vývoj skeletu s nižší tělesnou výškou než by odpovídalo kostnímu věku. Kromě PHP je AZ možno nalézt u jedinců s gonadální dysgenezí, brachydaktilií a ojediněle také s homocystinurií a také přibližně u 2-4\% zdravé populace.

Pro úplnost uvádíme ještě termín pseudopseudohypoparatyreóza (PPHP), což je označení pro pacienty s izolovanými projevy $\mathrm{AHO}$, ale s normálním metabolizmem kalcia a normální hodnotou PTH.

Podpořeno MZČR-RVO (FNBr 65269705). 